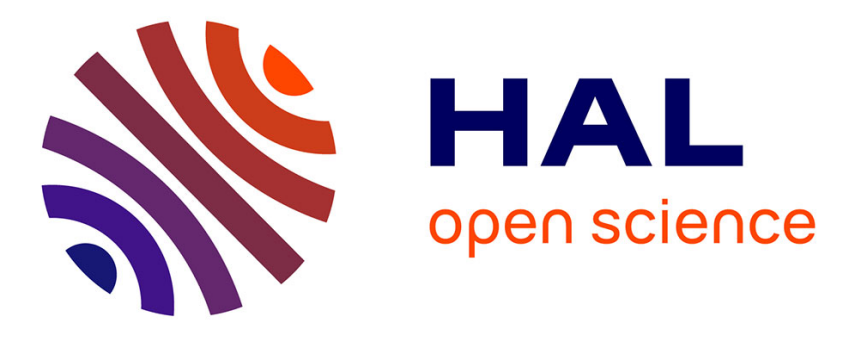

\title{
Seismic velocity structures of Southern Italy from tomographic imaging of the Ionian slab and petrological inferences.
}

Marco Calo', Catherine C. Dorbath, Dario Luzio, Silvio G. Rotolo, G. d'Anna

\section{- To cite this version:}

Marco Calo', Catherine C. Dorbath, Dario Luzio, Silvio G. Rotolo, G. d'Anna. Seismic velocity structures of Southern Italy from tomographic imaging of the Ionian slab and petrological inferences.. Geophysical Journal International, 2012, 191, pp.751-764. 10.1111/j.1365-246X.2012.05647.x . hal00755444

\section{HAL Id: hal-00755444 \\ https://hal.science/hal-00755444}

Submitted on 8 Nov 2021

HAL is a multi-disciplinary open access archive for the deposit and dissemination of scientific research documents, whether they are published or not. The documents may come from teaching and research institutions in France or abroad, or from public or private research centers.
L'archive ouverte pluridisciplinaire HAL, est destinée au dépôt et à la diffusion de documents scientifiques de niveau recherche, publiés ou non, émanant des établissements d'enseignement et de recherche français ou étrangers, des laboratoires publics ou privés.

\section{(c)(1)}

Distributed under a Creative Commons Attribution| 4.0 International License 


\title{
Seismic velocity structures of southern Italy from tomographic imaging of the Ionian slab and petrological inferences
}

\author{
M. Calò,${ }^{1,2}$ C. Dorbath, ${ }^{1,3}$ D. Luzio, ${ }^{2}$ S. G. Rotolo ${ }^{2,4}$ and G. D’Anna ${ }^{4}$ \\ ${ }^{1}$ EOST Institute, 5 rue René Descartes 67084 Strasbourg cedex, France.E-mail: calo@unistra.fr \\ ${ }^{2}$ CFTA Institute, Via Archirafi N 36, 90100 Palermo, Italy \\ ${ }^{3}$ IRD-UR234 (GET), Toulouse, France \\ ${ }^{4}$ INGV, Istituto Nazionale di Geofisica e Vulcanologia, Via Vigna Murata N 605, 00143 Roma, Italy
}

Accepted 2012 August 12. Received 2012 July 31; in original form 2011 August 26

\begin{abstract}
SUMMAR Y
In this study we have determined detailed Vp and Vs seismic velocity models of the Ionian lithosphere subducting beneath the Tyrrhenian basin and of the surrounding mantle, by applying a post-processing technique to a large sample of local earthquake tomography studies.

Our seismic velocity models permit us to infer the presence of low velocity anomalies within the slab, which we interpret as regions that are partially hydrated by fluids released during the subduction process. A petrological interpretation of the velocity anomalies gives new details on the magmatism of the volcanic Aeolian arc. Furthermore our velocity models provide a more detailed description of the boundary of the slab and its connection with the large seismically active Tindari-Letojanni strike slip system. Finally these results allow describing in detail some features of the slab as the presence of lateral and vertical tears. In conclusion, the obtained models provide some constraints for inferences on mantle circulation, and on the geodynamical evolution of the central-western Mediterranean.
\end{abstract}

Key words: Seismic tomography; Subduction zone processes; Rheology: crust and lithosphere.

\section{INTRODUCTION}

The tectonic setting of the Tyrrhenian-Apennine system (Fig. 1) is the result of a complex convergence $\left(0.6-0.8 \mathrm{~cm} \mathrm{yr}^{-1}\right)$ between the Eurasian and African plates (Anzidei et al. 1999; Hollenstein et al. 2003; Carminati \& Doglioni 2004; Rosenbaum \& Lister 2004), which has been active since the Cretaceous (145-65 Ma). After the Alpine orogenesis (55-28 Ma), the geodynamic evolution of the Tyrrhenian-Apennine system was driven by the eastward migration of the subduction of the Ionian lithosphere (Malinverno \& Ryan 1986). The presence of the Ionian slab is supported by the occurrence of intermediate and deep earthquakes, which define a Wadati-Benioff zone, from the surface to a depth of at least $500 \mathrm{~km}$ (Bruno et al. 1999 and references therein).

The Ionian lithosphere is about $125 \mathrm{~km}$ thick (Panza \& Suhadolc 1990; Gvirtzman \& Nur 2001; Pontevivo \& Panza 2006) and at least 130 Myr old (Catalano et al. 2001). It is composed of a 6-8 km thick Cenozoic ( $<65 \mathrm{Myr}$ ) sedimentary cover overlying a $8-9 \mathrm{~km}$ thick Mesozoic (150-130 Myr) oceanic crust; the latter is a remnant of the former Tethyan realm (Catalano et al. 2001). The remaining $100-110 \mathrm{~km}$ is composed of lithospheric mantle harzburgite (Blatt \& Tracy 1996).

The roll-back of the subducting Ionian slab $(10 \mathrm{Ma})$ produced the opening of the extensional backarc Southern Tyrrhenian basin (Kastens et al. 1988). At that time lithospheric rifting separated the Calabrian block from the Sardinian basement (Goes et al. 2004). This event led to the formation of new oceanic crust, which formed the Vavilov Basin to the west (4.3-2.6 Myr, Sartori 2003; 8.5-4.5 Myr, Argnani 2000), and the Marsili Basin to the south east (2.0-1.7 Ma, Argnani 2000; 1.6 Myr, Kastens et al. 1988).

Several studies (Peacock 2001; Dobson et al. 2002) reveal that deep-water circulation processes influence the occurrence of deep earthquakes, and the existence of a link between the ductile/brittle strain accommodation and hydration/dehydration reactions of slab/mantle mineral phases.

The subduction process carries water into the Earth's interior (Poli \& Schmidt 1995; Dobson et al. 2002 and references therein), while its subsequent release, through dehydration reactions, regulates the long-term budget of water on the planet's surface and the slip rate on the plate interface, controls plate buoyancy, and may trigger intraslab earthquakes and arc volcanism (Peacock \& Hyndmann 1999).

Hydration and dehydration reactions in the subducted ultramafics, by far the most volumetrically abundant rock type, have relevant effects on the mechanical properties of the rocks and consequently on $P$ - and $S$-waves velocities (Hacker et al. 2003).

If the subducting oceanic lithosphere is sufficiently cold and old, hydration (several wt. per cent $\mathrm{H}_{2} \mathrm{O}$ ) up to $6 \mathrm{GPa}$ (corresponding to depths of about $200 \mathrm{~km}$ ) results in 5-15 per cent lower seismic velocities than the surrounding mantle (Connolly \& Kerrick 2002; 


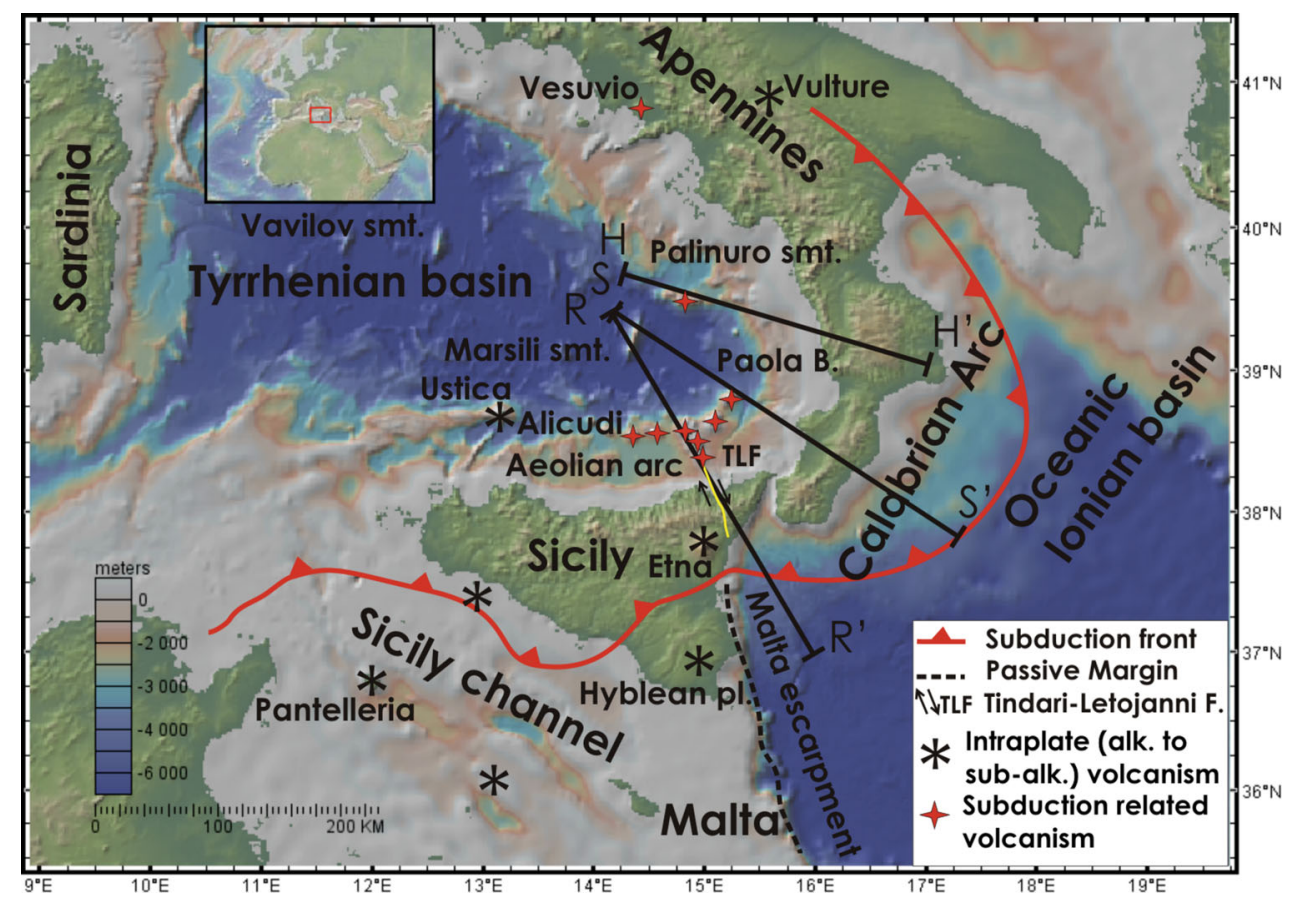

Figure 1. Schematic geological map of southern Italy. The red line is the contact between African and European plates. The Malta escarpment (black dashed line) is the passive margin, which collects the oceanic Ionian lithosphere to the Sicily channel region (continental part of the African Plate). The black lines (R-R', S-S' and H-H') are the traces of the vertical sections discussed in this work.

Hacker et al. 2003). Furthermore, Jung \& Karato (2001) suggested that water reduces the seismic wave velocity through enhanced anelasticity. Serpentinized harzburgite within the descending plate could form a potentially major reservoir for additional fluids (Peacock 2001; Rupke et al. 2004), and could hydrate the mantle immediately above the slab (Davies \& Stevenson 1992). The fluids released by dehydration reactions in the ultramafic portion of the slab are not uniquely destined to migrate into the overlying mantle wedge, but at least for steeply subducting slabs (more than $50^{\circ} \mathrm{dip}$ ), may in part flow up-dip within the slab (Abers 2005).

In the last decades, many tomographic studies (Piromallo \& Morelli 2003; Spakman \& Wortel 2004; Montuori et al. 2007; Chiarabba et al. 2008; Neri et al. 2009) have been performed to define the seismic velocity field in the crust and upper mantle beneath the Tyrrhenian-Apennine system in order to provide constraints for models of geodynamic evolution of the western Mediterranean Sea.

Nevertheless, the resolution of the velocity models of the region is still inadequate for investigating structure within the subducting lithosphere, and the velocity fields are not reliable enough to allow petrological inferences about the mineral phases existing at high pressure and temperature in this geodynamic context. Here we present $\mathrm{P}$ and $\mathrm{S}$ seismic velocity models of the Ionian slab obtained from high-resolution seismic tomography based on local earthquake data inversion (double-difference tomography tomoDD algorithm of Zhang \& Thurber 2003), further optimized by applying the weighted average model method (WAM; Calò 2009; Calò et al. 2009, 2011). Application of the double-difference tomography method to other regions has revealed new structural details within downgoing slabs, providing direct constraints on the petrological models, e.g. in northern Japan (Zhang et al. 2004) or in northern Chile (Dorbath et al. 2008).

After the WAM method reliability assessment, we interpret the resulting velocity anomalies in terms of phase equilibria governing the progressive dehydration of silicates in the ultramafic portion of the subducted lithosphere. These observations provide relevant insights on the possible influence of intraslab mineralogy with the $\mathrm{H}_{2} \mathrm{O}$-release/retention.

\section{DATA SELECTION}

The data employed by this study are the first arrival times of $P$ and $S$ waves, for earthquakes located in the southern Tyrrhenian and recorded during the period 1981-2005 by national (Istituto Nazionale di Geofisica e Vulcanologia; INGV) and local seismic networks. The data set was updated with arrival times, not included in the INGV catalogues, picked out on waveforms recorded from three temporary arrays (in 1993, 1994 and 2002).

The seismicity of the region can be subdivided into two main subsets (Fig. 2). The first set contains the shallow earthquakes (hypocentral depth less than $40-50 \mathrm{~km}$; blue points in Fig. 2) produced by the brittle behavior of the upper portion of the thinned southern Tyrrhenian lithosphere. The second set contains the deep events (hypocentral depth down to 500-600 km; green points in Fig. 2) mostly located in the eastern part of the southern Tyrrhenian Sea, between the Aeolian archipelago and the Calabrian coastline. The hypocenters of this latter set are located in a well-developed Wadati-Benioff zone having average dip of $69^{\circ}-72^{\circ}$ (at depth of 100-300 km) and NW polarity (Chiarabba et al. 2005; Calò et al. 2009; Neri et al. 2009). We have performed preliminary hypocentral locations and optimizations of the 1-D Vp and Vs input models using a procedure that optimizes the hypocentral coordinates, the velocity models and the mean station residuals by minimizing besides the L2 norm of the residuals times their coherence in the offset domain (Giunta et al. 2004; Calò 2009).

We have used a subset of 1,800 earthquakes containing both shallow and deep events down to a depth of $350 \mathrm{~km}$ (419 events 


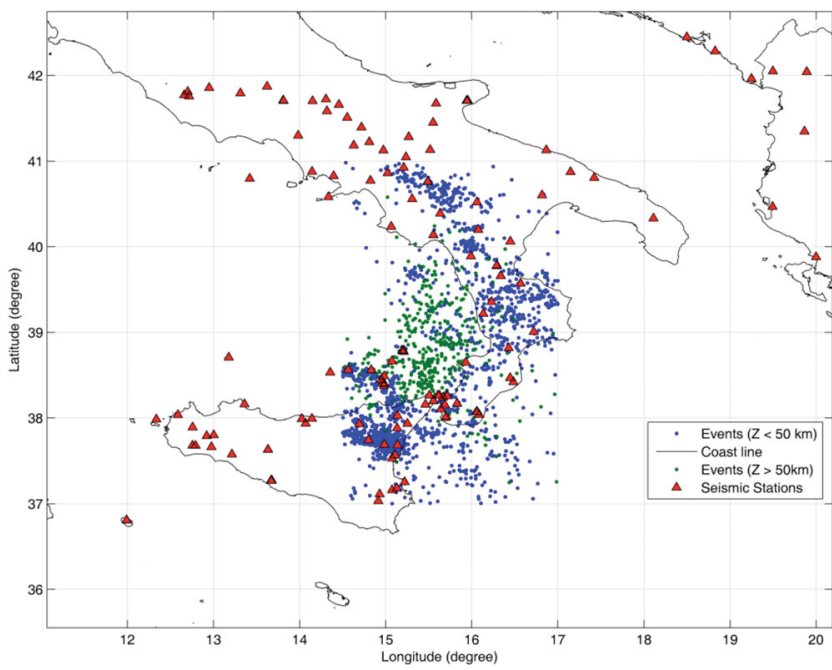

Figure 2. Map with the earthquakes (dots) and seismic array (red triangles) used to obtain the $\mathrm{Vp}$ and $\mathrm{Vs}$ models. Blue dots are the shallow events $(\mathrm{Z}<$ $50 \mathrm{~km})$ while the green dots are the deeper ones $(\mathrm{Z}>50 \mathrm{~km})$.

located between 40 and $350 \mathrm{~km}$ of depth; Figs 2 and 3), to construct seismic velocity models using the TomoDD inversion code (Zhang $\&$ Thurber 2003). Subsequently, we have applied the WAM postprocessing method (Calò 2009).

The events of our subset were recorded by at least 10 stations and fit the observed data with RMS (weighted mean square residual) less than $0.50 \mathrm{~s}$ after relocation with an optimized 1-D model (Calò
2009). The data set consists of $28,873 \mathrm{P}$ - and $9,990 \mathrm{~S}$ - absolute arrival times recorded by 183 seismic stations and mostly located inside the target area, supplemented by $55,467 \mathrm{P}-$ and $23,992 \mathrm{~S}-$ differential times.

When a LET (local earthquake tomography) technique is applied to study subduction zones it is necessary to reconstruct properly the crustal heterogeneities, because these affect the ray-paths of the deep events, and theirs related travel times.

The data set was chosen to allow reliable reconstruction of the Vp and Vs distributions even in the shallow layers of the investigated volume. Fig. 3 shows the projection of the $P$ wave ray-paths as straight lines on a horizontal and N-S and W-E vertical planes.

\section{CONSTRUCTION OF THE VELOCITY MODELS AND THE WAM TECHNIQUE}

The velocity models presented in this study are the result of a procedure that allows high resolution and reliability of the obtained velocity distributions. In this procedure we first ran the tomoDD code (Zhang \& Thurber 2003) to solve the Vp and Vs structures and hypocentral locations. Then the post-processing WAM method (weighted average model) was run to increase the volume of investigation and to improve the reliability of the velocity models (Calò 2009; Calò et al. 2009, 2011).

The double-difference tomography code (Zhang \& Thurber 2003) has been developed to solve event locations and velocity structure simultaneously by using both absolute and differential travel-time data. This process overcomes the limitation of the double-difference
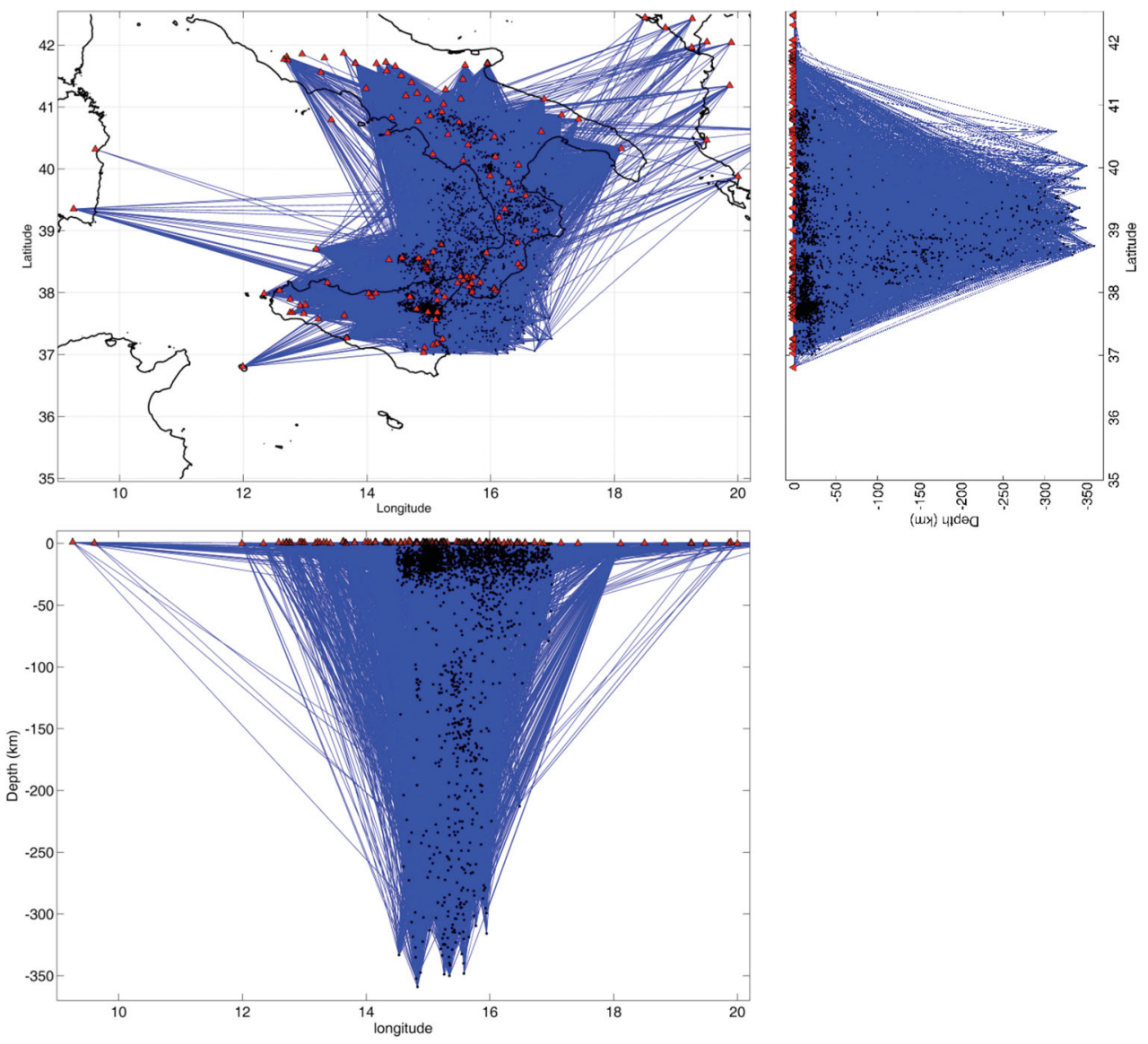

Figure 3. $P$-wave ray paths traced as straight lines. Earthquakes and seismic stations are indicated by black points and red triangles, respectively. 
location method (Waldhauser \& Ellsworth 2000) by taking into account explicitly the path anomaly biases between pairs of events. In theory, double-difference tomography has the ability to relocate accurately large numbers of earthquakes both in absolute and relative locations as well as to characterize more precisely the local velocity structure. Many areas have been studied by using this technique at local and regional scale (Zhang \& Thurber 2003; Shelly et al. 2006; Dorbath et al. 2008), allowing a detailed description of the $\mathrm{Vp}$ and Vs velocity structures within slabs.

The observed differential arrival times can be calculated from both waveform cross correlation techniques for similar waveforms and absolute catalogue arrival times. In our work we calculated differential times from the absolute arrival times catalogue only.

However, also in tomoDD the initial parameters that are imposed to obtain the 3-D velocity models (e.g. initial model velocity values, model parameterization, data selections, etc.) may strongly affect the results.

Therefore we applied the WAM method (Calò 2009; Calò et al. 2011) to overcome some limitations of the velocity models obtained with the standard tomographic codes. The WAM method is a post-processing technique that may be used with any tomographic inversion code. This method is based on sampling models compatible with data sets using different input parameters and then synthesizing results in a weighted average model.

Several tests, carried out with both synthetic and experimental data (Calò 2009), have shown that as the order N of the WAM increases (i.e. the number of the models used to construct the WAM), the resulting model tends asymptotically to the true velocity distribution. The method is therefore able to reconstruct velocity distributions more reliably than a generic single tomographic inversion.

We obtained final $\mathrm{P}$ and $\mathrm{S}$ velocity distributions by averaging, with the WAM method, 27 double-difference tomography models obtained with different input parameters. In particular, besides some tomographies performed using various selection rules of absolute and differential data, others carried out with 1-D and 3-D starting models and with deformed and translated grids, we picked out several inversions relative to different azimuth of the horizontal edges of the initial inversion grid. The average angular step of the rotations was about $20^{\circ}$ and the total azimuth coverage was $180^{\circ}$ (Calò et al. 2009; Calò 2009).

Fig. 4 shows horizontal and vertical sections of the checkerboard test (Zhao et al. 1992) obtained with the same procedure described above. This test was carried out with a synthetic data set containing the calculated absolute and differential data corresponding to the experimental distribution of events and stations, perturbed by random errors with a standard deviation proportional to the mean location RMS.

The test shows that bodies characterized by 6 per cent velocity contrasts and with average dimension of $28 \mathrm{~km} \times 28 \mathrm{~km} \times$ $24 \mathrm{~km}$ (X, Y and Z, respectively) are well recovered in the investigated volume. For this work the investigated volume is defined by considering the part of the model with derivative weight sum (DWS, Toomey \& Foulger 1989) greater than 100. Furthermore, we determined the weighted standard deviations (WSD) of the WAM velocity estimates to assess the reliability of the resulting model. The WSD parameter is useful to evaluate the dependence of the inversion results on the input parameters used to reconstruct each model. We observed by synthetic tests that WSD is strongly anticorrelated to the restoration of the true velocities (Calò et al. 2008, 2009; Calò 2009). In most of the investigated volume, the WSD values are smaller than $0.06 \mathrm{~km} \mathrm{~s}^{-1}$, and do not exceed $0.12 \mathrm{~km} \mathrm{~s}^{-1}$ in the border areas (Calò et al. 2009).
In Appendix A the results obtained by the inversions of two completely independent subsets of events are also reported. The subsets were constructed selecting events with odd and even numbers in the earthquake list in order to get a random distribution of the data. Each subset contains 900 events. This test allows estimating the contribution of the random noise in the reconstruction of the velocity model (Koulakov et al. 2009).

The sections S-S' (Appendix A) show that the velocity models are very similar at all depths. The models should be compared between them and also to the model obtained with the whole data set. The $\mathrm{Vp}$ and Vs sections report very similar velocity structures for the three data sets.

This test demonstrates that the noise included in our data does not influence significantly the inversion results, supporting the reliability of the obtained velocity models.

However, we have to note that the small differences observed between the models should also be related to the lower resolving power of the experimental information in the inversions performed with the two subsets with respect to the results obtained with the whole data set because they were calculated only with half of the data.

In the following paragraphs we discuss the results of our 27th order WAM tomography. The main features of the final $\mathrm{Vp}$ and Vs models were stable in the sampling of the model space carried out within the WAM procedure. Furthermore, we carried out many inversions with different 1-D and 3-D input models (Calò et al. 2009). For these inversions we tested perturbations of the initial model that reach 13 per cent of the initial seismic velocities.

Similar tests were performed to assess the reliability of the Vs model. Also these tests provided good results although the resolved region is much smaller because of the smaller amount of data.

Finally, checkerboard test together with the other assessment tests already presented in Calò et al. (2009) and Calò (2009), support the reliability of the detailed velocity models obtained through doubledifference tomography followed by WAM post-processing.

\section{TOMOGRAPHIC RESULTS}

The main results of the southern Tyrrhenian Vp and Vs velocity models are presented in four horizontal slices (Fig. 5) and three vertical sections (H-H', S-S' and R-R'; Figs 1 and 6) that are representatives of the studied area. For the description (and the interpretation) of the seismic velocity anomalies we assume a thickness of the Ionian lithosphere of $125 \mathrm{~km}$, as suggested by several authors (Panza \& Suhadolc 1990; Gvirtzman \& Nur 2001; Pontevivo \& Panza 2006).

\subsection{Horizontal Vp and Vs slices}

The Vp section at a depth of $80 \mathrm{~km}$ (Fig. 5a) shows a high velocity body $\left(8.2<\mathrm{Vp}<8.8 \mathrm{~km} \mathrm{~s}^{-1}\right.$, label 1$)$ that dominates most of the investigated area. This body represents the top of the Ionian slab. At this depth the Ionian slab is dipping about $20^{\circ}-30^{\circ} \mathrm{NW}$ and it appears limited in the northeastern and southwestern part (black dashed lines). A thin lower $\mathrm{Vp}$ area $\left(7.0<\mathrm{Vp}<7.7 \mathrm{~km} \mathrm{~s}^{-1}\right.$, label 2), elongated in NNE-SSW direction, is also noticeable inside the Ionian slab. The corresponding Vs section (Fig. 5e) shows a high velocity body $\left(4.75<\mathrm{Vs}<5 \mathrm{~km} \mathrm{~s}^{-1}\right.$, label 1$)$ that is thinner in the central region, and a larger low anomaly beneath the Calabrian Arc $\left(3.8<\mathrm{Vs}<4.2 \mathrm{~km} \mathrm{~s}^{-1}\right.$, label 2). The two boundaries of the Ionian 


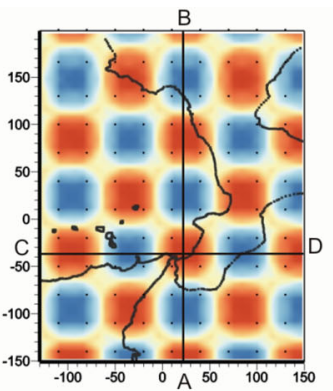

a

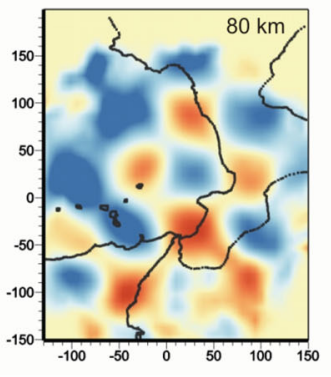

d

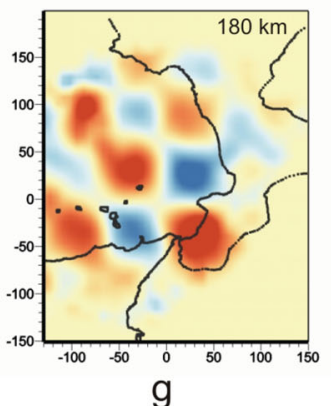

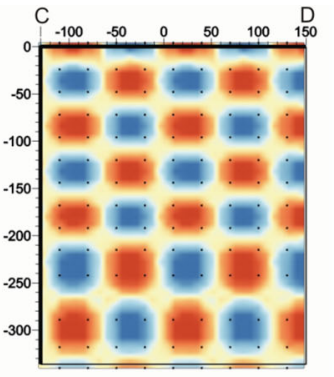

b

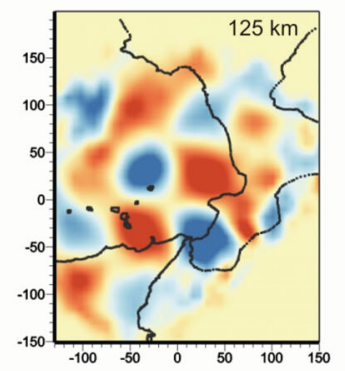

e

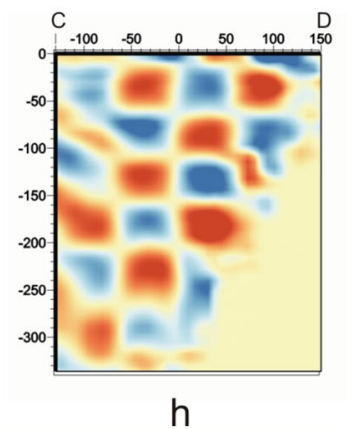

$\mathrm{Vp}(\%)$

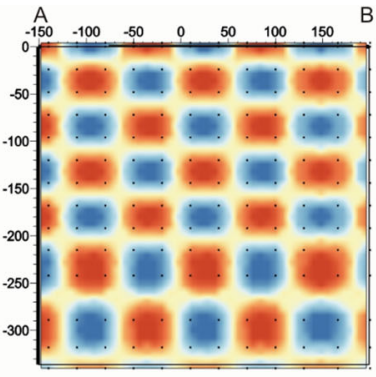

C

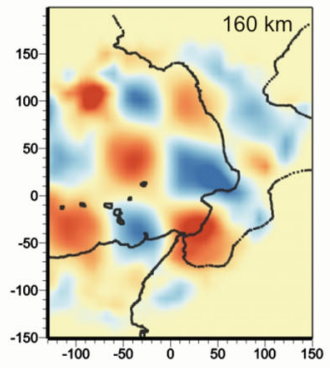

$f$

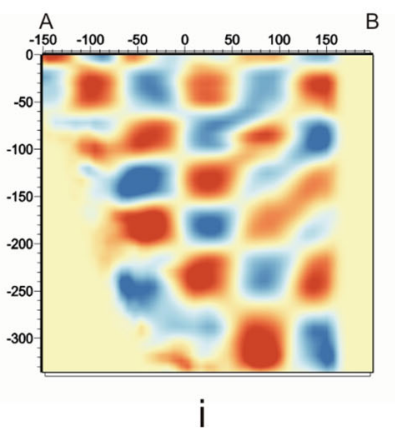

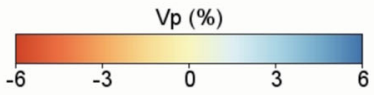

Figure 4. Horizontal (a) and vertical (b and c) sections of the initial checkerboard velocity model. Horizontal sections of the reconstructed checkerboard model are at depths of $80 \mathrm{~km}(\mathrm{~d}), 125 \mathrm{~km}(\mathrm{e}), 160 \mathrm{~km}(\mathrm{f})$, and $180 \mathrm{~km}(\mathrm{~g})$. Vertical sections of the reconstructed checkerboard model (h and i).

slab observed in the Vp section are also visible in this model (black dashed lines).

At a depth of $125 \mathrm{~km}$ (Fig. 5b), the dip angle of the subducting lithosphere is about $69^{\circ}-72^{\circ}$ down to $250-300 \mathrm{~km}$ of depth (see Fig. 6). The high $\mathrm{Vp}$ body characterizing the Ionian slab is very narrow (about $50 \times 50 \mathrm{~km}^{2}$ large, label 1) and mostly located in the eastern part of the southern Tyrrhenian Sea. Low Vp anomalies $\left(7.0<\mathrm{Vp}<7.7\right.$, label 2) covering an area of about $25 \times 35 \mathrm{~km}^{2}$ are located beneath the Calabrian arc. Low Vp areas (label 3) are also observed beneath the Aeolian archipelago and NW (i.e. beneath the Marsili basin). In the horizontal section of the Vs model (Fig. 5f), the high seismic velocitiy values involve a larger area (label 1). They are placed beneath the northern coastline of the Calabria and in the westernmost part of Sicily. Low Vs regions are observed in the southern part of the resolved area (beneath southern Calabria and Sicily, label 2) and beneath the Aeolian archipelago (label 3).

The slice at a depth of $160 \mathrm{~km}$ (Fig. 5c) clearly shows the concave shape of the Ionian slab (black dashed line), here highlighted by a 50-60 km large and 200-220 km long high velocity anomaly (label 1). In this slice the low $\mathrm{Vp}$ area just beneath the Calabrian arc is somewhat discontinuous (label 2). The low velocity regions located NW of the Aeolian arc are still present (label 3). At this depth the Vs model (Fig. 5g) shows only a fragmented distribution of the high values beneath the Tyrrhenian Sea (label 1) and few low anomalies beneath the Calabrian arc (label 2).

The slice at a depth of $180 \mathrm{~km}$ (Fig. 5d) shows a clear sandwich structure of the Ionian slab characterized by a thin $(20-25 \mathrm{~km}$, label 2) low velocity layer between two high $\mathrm{Vp}$ zones (label 1). It is worth noting that at this depth the low Vp anomalies beneath the Marsili area are no longer imaged. The corresponding Vs section (Fig. 5h) displays an elongated high velocity anomaly $30-50 \mathrm{~km}$ large $\left(4.75<\mathrm{Vs}<5 \mathrm{~km} \mathrm{~s}^{-1}\right.$, label 1) that separates two low Vs bodies $\left(3.8<\mathrm{Vs}<4.2 \mathrm{~km} \mathrm{~s}^{-1}\right)$ located beneath the Calabrian arc (label 2) and in the northwestern part of the Aeolian Archipelago (label 3), respectively.

\subsection{Cross section $\mathrm{S}-\mathrm{S}$}

The S-S' vertical section, which crosses the central part of the study area (Figs 1 and $6 \mathrm{~b}$ and e), shows that the upper portion of the 

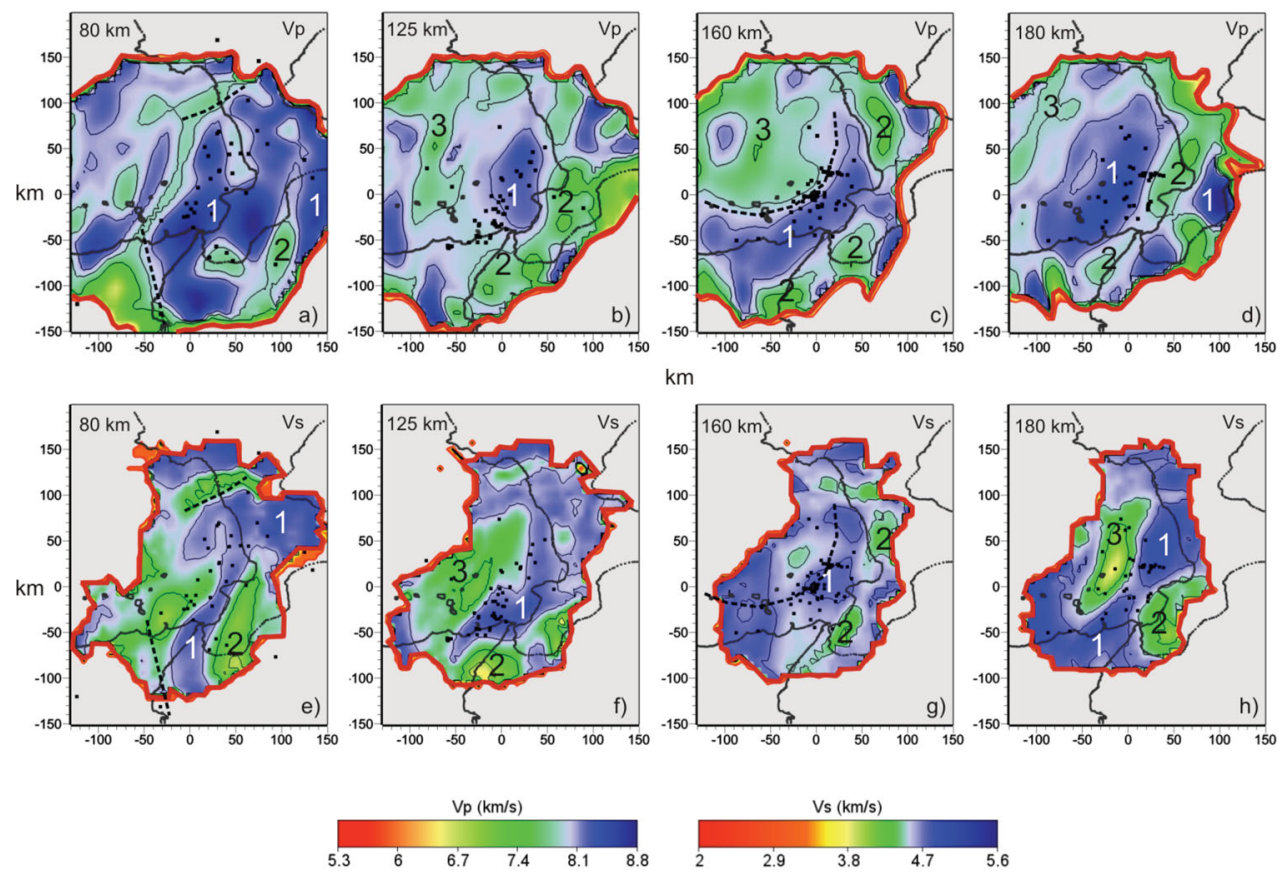

Figure 5. Horizontal sections of the Vp and Vs models at depths of 80,125, 160 and $180 \mathrm{~km}$. Red lines limit the well-constrained areas of the model (DWS > 100). The black dashed lines on the sections at a depth of $80 \mathrm{~km}$ are referred to the vertical tears bordering the Ionian slab. The black dashed line on the sections at a depth of $160 \mathrm{~km}$ highlights the arcuate shape of the subducting lithosphere. The labels (1,2 and 3) mark the high/low velocities discussed in this work.
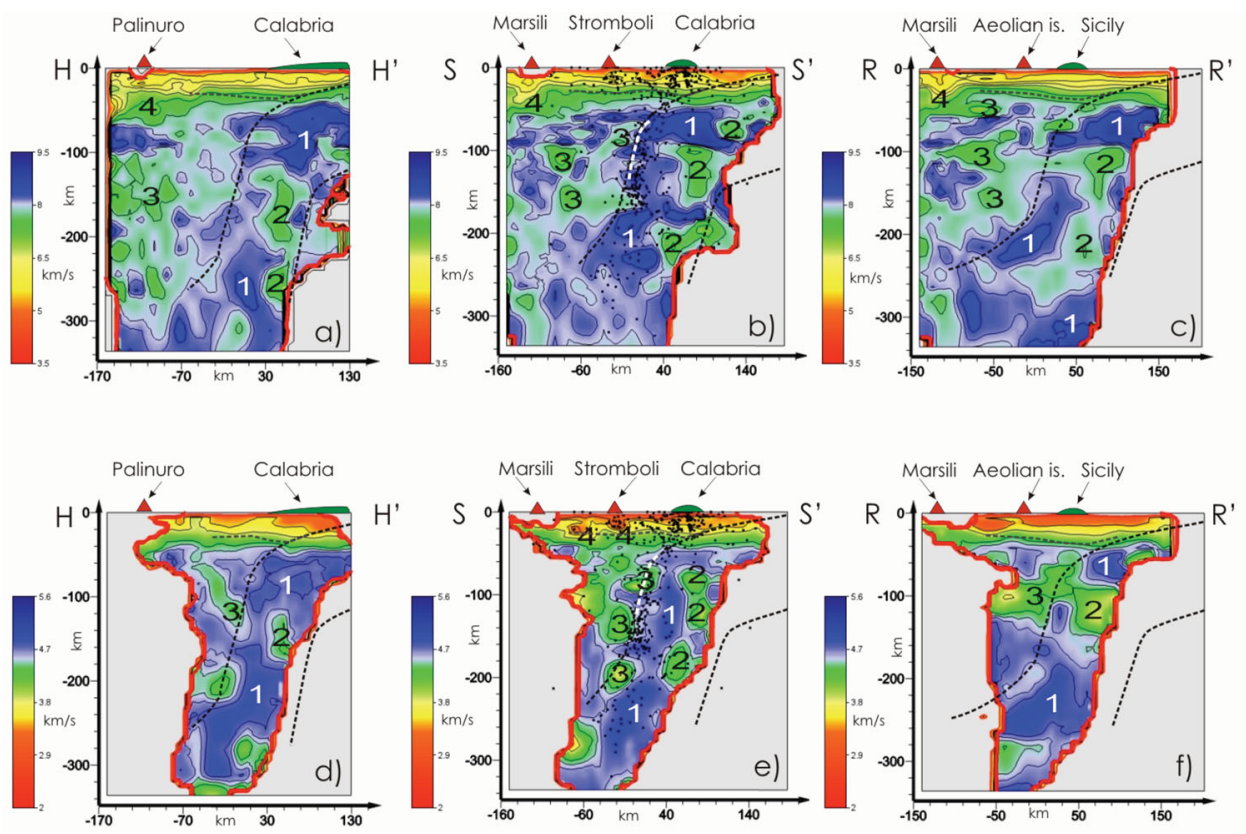

Figure 6. Vertical sections of the $\mathrm{Vp}(\mathrm{a}, \mathrm{b}$ and $\mathrm{c})$ and $\mathrm{Vs}(\mathrm{d}$, e and $\mathrm{f}$ ) models. The black dashed lines in all the sections are the schematization of the estimated thickness of the subducting Ionian lithosphere, while the red lines limit the well-constrained areas of the models (DWS $>100)$. The white dashed line in S-S' is the projection of the top of the Ionian slab detected by Finetti (2005). The black dots in S-S' are the projections of the earthquakes within $15 \mathrm{~km}$ of the section. The labels (1, 2, 3 and 4) mark the high/low velocities discussed in this work.

slab is characterized by high values of both $\mathrm{Vp}$ and $\mathrm{Vs}(8.2<\mathrm{Vp}<$ $8.8 \mathrm{~km} \mathrm{~s}^{-1}$ and $\left.4.75<\mathrm{Vs}<5 \mathrm{~km} \mathrm{~s}^{-1}\right)$. The thickness of this continuous body (label 1 in Fig. 6) is 50-60 km and it dips steeply, together with the hypocenters, towards the NW with an approximative angle of $69^{\circ}-72^{\circ}$ calculated in the part of the slab at $100-300 \mathrm{~km}$ of depth.

Just below the high Vp and Vs zone, a thin heterogeneous area composed of separate bodies (label 2 in Fig. 6) having values of
$7.0<\mathrm{Vp}<7.7 \mathrm{~km} \mathrm{~s}^{-1}$ and $3.8<\mathrm{Vs}<4.2 \mathrm{~km} \mathrm{~s}^{-1}$ is visible. The size of these anomalies ranges between 20 and $30 \mathrm{~km}$ in the horizontal direction, and 30 and $50 \mathrm{~km}$ in the vertical one.

The portion of the slab underlying the low velocity bodies (that is expected to have a thickness around 30-50 km assuming a $125 \mathrm{~km}$ thick subducting lithosphere) is visible only in a few parts of our models. 


\subsection{Cross section $\mathrm{H}_{-} \mathrm{H}^{\prime}$}

The H-H' section crosses the northeastern part of the subducting slab (Fig. 1). Compared with the S-S' section, the high Vp (and Vs) bodies, corresponding to the upper part of the Ionian subducted slab (label 1 in Figs 6a and d), is rather discontinuous. In particular this body seems broken between 120 and $210 \mathrm{~km}$ depth in the $\mathrm{Vp}$ section and between 120 and $180 \mathrm{~km}$ in the Vs one. Just below the high velocities, the steeply elongated low $\mathrm{Vp}$ and Vs anomaly is still present (label 2 in Figs 6a and d). The horizontal and vertical dimensions of this low velocity anomaly are about $30 \mathrm{~km}$ and $70 \mathrm{~km}$, respectively. The deep low Vp bodies beneath the Tyrrhenian Sea are also present, but they are confined to the northeastern part (labels 3 and 4 in Fig. 6a). This region of the southern Tyrrhenian basin is approximately below the Palinuro seamount. If we assume a Vp of 7.6-7.8 $\mathrm{km} \mathrm{s}^{-1}$ for the upper mantle of the Tyrrhenian basin (Chironi et al. 2000; Caielli et al. 2003 and references therein), the thickness of the Tyrrhenian crust results of 20-25 km, marked by a slight thinning towards offshore Calabria (grey dashed line in Figs $6 a$ and d). Finally, a shallow low Vs anomaly reaching a depth of $15-18 \mathrm{~km}$ can be assigned to the upper crust and to the thick plio-quaternary sedimentary cover (i.e. the Paola basin, Pepe et al. 2008).

\subsection{Cross-section R-R'}

This vertical section crosses the southwestern part of the Ionian slab the Sicily and the Aeolian archipelago (Fig. 1). It displays the high $\mathrm{Vp}$ body at the top of the slab detached by a thin subhorizontal low velocity anomaly between 90 and $130 \mathrm{~km}$ (label 2 in Figs 6c and f). Vs section shows a clear and larger low velocity anomaly separating the high velocity bodies.

In the Tyrrhenian mantle wedge, the lowest $\mathrm{Vp}$ and Vs values are mostly located between the Aeolian archipelago and the Marsili seamount (labels 3 in Figs 6c and f). At shallow depths (down to $30-40 \mathrm{~km}$ ) the low $\mathrm{Vp}$ anomalies are mostly located beneath the major volcano of the region (i.e. the Marsili seamount, label 4 in Fig. 6c) and beneath the Aeolian Islands. The high Vp that characterizes the Ionian slab almost completely surrounds a vertically elongated low Vp anomaly at a depth of 100-250 km. In the cross-section the thinning of the Tyrrhenian crust from Sicily towards offshore is also noticeable (gray dashed line in Figs $6 \mathrm{c}$ and $\mathrm{f}$ ). This crustal thinning is in agreement with the results of several studies carried out in the same region (Chironi et al. 2000; Caielli et al. 2003; Pontevivo \& Panza 2006; and references therein).

\section{COMPARISON WITH PREVIOUS STUDIES}

Several seismic tomographic techniques have been applied for studying the Ionian subduction zone. Vertical sections of recent velocity models obtained with teleseismic data (Piromallo \& Morelli 2003; Spakman \& Wortel 2004; Montuori et al. 2007; Koulakov et al. 2009) show high Vp bodies steeply dipping to about the $660 \mathrm{~km}$ discontinuity. All the authors agree that these bodies belong to the Ionian lithosphere subducting beneath the Tyrrhenian basin. The thickness of these bodies is different in the models of various authors; nevertheless it seems to be at least $80-110 \mathrm{~km}$ at depths ranging between 100 and $300 \mathrm{~km}$. However, the resolution of these velocity models is low (vertical and horizontal resolutions are estimated between 50 and $100 \mathrm{~km}$; Piromallo \& Morelli 2003; Spakman \& Wortel 2004; Montuori et al. 2007), and thus only a qualitative comparison with our results can be made. Recently, models providing a more detailed description of the geometry of the Ionian subducting slab have been obtained by inversion of local earthquake data. Neri et al. (2009) show, in agreement with our results, a high $\mathrm{Vp}$ body that is continuous in the central part of the slab and is laterally interrupted, while Chiarabba et al. (2008) focused their attention on the relationships between the low Vp anomalies detected in the Tyrrhenian mantle wedge and the fluids released by the subducted Ionian lithosphere. In both models the thickness of this high $\mathrm{Vp}$ body is $50-60 \mathrm{~km}$ and its position is in agreement with our results. However, the mean spatial resolution of the models of Neri et al. (2009) and Chiarabba et al. (2008) is about $50 \mathrm{~km}$ for a depth ranging from 50 to $350 \mathrm{~km}$. This resolution is similar to that of the above mentioned teleseismic tomography models. Chiarabba et al. (2008) used the tomographic inversion code developed by Thurber (1993) and modified by EberhartPhillips \& Reyners (1997) while Neri et al. (2009) used the standard Simulps code (Evans et al. 1994). Both methods use only the absolute travel times to determine the velocity model and hypocenter locations.

In this work we used the tomoDD code (Zhang \& Thurber 2003) that uses absolute and differential travel times to solve for both the $\mathrm{Vp}$ and Vs structures and the hypocenter locations. Moreover the WAM method increased the extension of the investigated volume, and the resolution and reliability of the final velocity models (Calò 2009). Furthermore, we have verified that velocity anomalies of $28 \mathrm{~km} \times 28 \mathrm{~km} \times 24 \mathrm{~km}$ are well recovered with the data set we have used (Calò 2009).

The largest low Vp anomaly detected in the R-R' section had been roughly imaged by Chiarabba et al. (2008), because its horizontal dimension is estimated to be about $40 \mathrm{~km}$, while the low Vp anomaly of the H-H' section is comparable to that shown in the model of Neri et al. (2009). The partial absence of the smallest velocity anomalies within the slab in the above-mentioned models can be explained as a lack of resolution (they are inadequate resolving features smaller than $50 \mathrm{~km}$ ). They also lack detailed information on the structure of the deeper (and inner) part of the Ionian slab.

Finally, Neri et al. (2009) calculated only the Vp velocity model (using only $P$-wave travel times) while Chiarabba et al. (2008) used also S-P times to calculate Vp/Vs model. In our work we used P-and $\mathrm{S}$-travel times to determine simultaneously $\mathrm{Vp}, \mathrm{Vs}$ and hypocentre locations.

The high resolution of our models (especially of the deepest parts) is therefore due to three major aspects. First, we used deep and shallow events to calculate the velocity models. The presence of 'short' ray paths related to the shallow events allows a high resolution and reliability of the shallow structures. Consequently, the parts of the 'longer' ray paths, mainly related to the deeper events, result more constrained and able to better resolve deeper structures. Second, we used double difference data. These data are able to increase the resolution of the seismic velocities near the foci (Zhang \& Thurber 2003). This leads in a general improvement of the whole model and consequently of the deeper structures. Third, the post processing WAM method allowed a strong limitation of artefacts because it reduces the dependence of the model from the input parameters. We thus conclude that the double-difference tomography together with the use of our post-processing method allows obtaining more detailed and more reliable velocity models than the previous studies. 


\section{THE IMAGE OF THE IONIAN SLAB AND PETROLOGICAL INFERENCES}

The velocity models we have obtained suggest that the Ionian slab has a sandwich structure characterized with lower seismic velocity regions inserted within a region of higher seismic velocities.

Eclogite (former oceanic crust; $8.4<\mathrm{Vp}<8.7 \mathrm{~km} \mathrm{~s}^{-1}$ ) and anhydrous harzburgite (upper mantle; $8.4<\mathrm{Vp}<8.8 \mathrm{~km} \mathrm{~s}^{-1}$ ) have similar seismic velocities at depth (Hacker et al. 2003), and therefore are virtually undistinguishable in a LET. Since Catalano et al. (2001) suggest an Ionian oceanic crust to be $8-10 \mathrm{~km}$ thick, we interpret the high $\mathrm{Vp}$ (and Vs) layers in the upper portion of the descending slab to be most likely composed of: (i) $\sim 10 \mathrm{~km}$ of eclogite, and (ii) $\sim 50 \mathrm{~km}$ of anhydrous harzburgite.

Seismic profiles performed in the area with the near-vertical reflection technique (CROP project; Finetti 2005) detected a thin, strongly sloping reflective layer down to a depth of about $140 \mathrm{~km}$, which has been interpreted as the top portion of the Ionian slab (white dashed line in the S-S' cross section). Our Vp and Vs velocity distributions match well the interpretation of Finetti (2005), and the accuracy of the dip estimation and position of the Ionian slab.

Just below, i.e. most likely in the Ionian lithospheric mantle, there is a $20-25$ thick zone characterized by low $\mathrm{Vp}\left(7.0-7.7 \mathrm{~km} \mathrm{~s}^{-1}\right)$ and Vs $\left(3.8-4.2 \mathrm{~km} \mathrm{~s}^{-1}\right)$.

This zone is coincident with the inner, probably colder, portion of the slab. We interpret these velocities as partially hydrated (serpentinized) harzburgite areas separated by protrusions, perhaps corresponding to less hydrated mantle regions. Serpentinite is also characterized by low elastic wave velocities and high Poisson's ratio (Christensen 2004). The relation between decrease of Vp and increasing of the serpentinization in peridotites (Christensen 2004) suggests that values of $\mathrm{Vp}$ down to $7.0 \mathrm{~km} \mathrm{~s}^{-1}$ can be achieved with a serpentinization of peridotite that could reach $20-30$ per cent in volume. It is worth noting that this low-velocity region is practically aseismic, in agreement with the ductile rheology of serpentine-bearing rocks (Peacock \& Hyndmann 1999). These lowvelocity bodies disappear at a depth of $230-250 \mathrm{~km}$, which is close to the experimentally determined upper pressure bound required for the stability of antigorite-chlorite assemblages in hydrous peridotites: ca. 6.0 GPa at $600{ }^{\circ} \mathrm{C}$ according to Fumagalli \& Poli (2005) or a slightly higher pressure according to Hacker et al. (2003). The vanishing of the low-velocity region at a depth greater than $230 \mathrm{~km}$ could thus be ascribed to substantial dehydration of the serpentinegroup minerals to $\mathrm{H}_{2} \mathrm{O}$-poor high-pressure DHMS phases (dense hydrous magnesian silicates, e.g. the 'phase A'). These latter are closely similar to anhydrous lherzolite minerals in their seismic properties (Hacker et al. 2003).
The Vp and Vs WAMs display a mantle wedge in the Tyrrhenian region, on the top of the Ionian slab, with low-velocity vertically elongated areas $\left(\mathrm{Vp} \leq 7.0 \mathrm{~km} \mathrm{~s}^{-1}\right.$ and $\left.\mathrm{Vs} \leq 4 \mathrm{~km} \mathrm{~s}^{-1}\right)$ beneath the Stromboli and Marsili volcanoes (label 3 in Figs 5 and 6). The $\mathrm{Vp} / \mathrm{Vs}$ distribution (obtained by dividing the two velocity models; Appendix B), shows that these areas are marked by high values $(\mathrm{Vp} / \mathrm{Vs}>1.8)$. The spatial distribution of these lowvelocity and high $\mathrm{Vp} / \mathrm{Vs}$ ratio bodies suggests that partial melting triggered by a reservoir of slab-released fluids is likely to occur at a depth $\leq 180 \mathrm{~km}$. This depth is in a good agreement with the Vp model of Chiarabba et al. (2008), experimental petrology constraints (Schmidt \& Poli 1998) and geochemical/petrological models (Tommasini et al. 2007). The major volcanological inference is that beneath Stromboli and Marsili volcanoes (at depth $\leq 40 \mathrm{~km}$ ) significant amounts of mantle partial melts (i.e. some thousands of $\mathrm{km}^{3}$ ) have accumulated, and feed the present-day volcanic activity (label 4 in Fig. 6).

Fig. 7a summarizes the main features of the velocity models discussed in the S-S' cross-section and illustrates two possible pathways for the fluids released by dehydration of the ultramafic portion of the slab: (i) an up-dip migration (within the subducted ultramafic lithosphere) enhancing hydration of more superficial ultramafic rocks, and (ii) a migration through transverse channels, (e.g., bend faults, Kerrick 2002; Ranero et al. 2003), which can deliver the fluids to the top of the subducted crust and hence to the overlying mantle wedge. The dip angle and the depth reached by the faults are mostly affected by the bending of the trench zone (Ranero et al. 2003) identified bend faults dipping $45^{\circ}$ and cutting at least $20 \mathrm{~km}$ into the Nicaragua slab that is dipping $65^{\circ}$. The Vp horizontal section at a depth of $80 \mathrm{~km}$ shows a low $\mathrm{Vp}$ area with elongated shape in SW-NE direction inside the upper part of the subducting lithosphere (Fig. 5 label 2). This main direction is almost parallel to the bending axis of the slab and hence with the direction of the bend faults. Therefore we suggest that a similar scenario occurs in the Ionian slab in the bending caused by the steep roll-back, where deep bend faults affect the subducting lithosphere allowing the hydration of large volume of the Ionian upper mantle.

\section{GEODYNAMICAL IMPLICATIONS AND CONTRIBUTIONS OF THE NEW IMAGES OF IONIAN SLAB}

The horizontal slices of the Vp and Vs models (Fig. 5) show an Ionian slab that changes in size with depth. In the Vp its lateral extension varies between 80 and $160 \mathrm{~km}$ reaching the minimum (i.e. its maximum lateral shortening) at a depth of $125 \mathrm{~km}$.

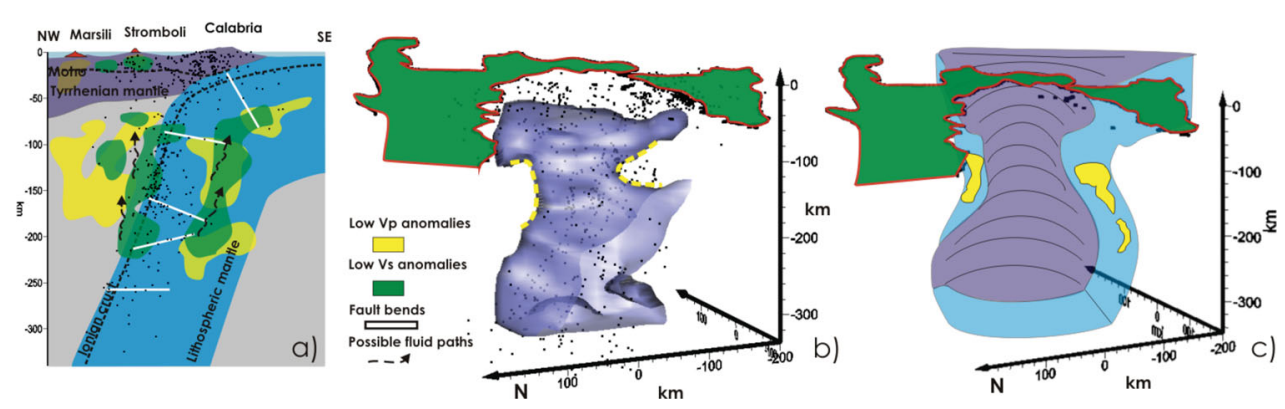

Figure 7. (a) Sketch displaying the velocity anomalies detected on S-S' Vp and Vs sections; (b) 3-D representation of the high Vp (>8.15 km s $\left.{ }^{-1}\right)$ Ionian slab. The yellow dashed lines mark the lateral shortening of the slab, while the black dots are the earthquakes used in this work; (c) 3-D sketch showing the shape of the subducting slab and the relative positions of the low velocity anomalies within the Ionian lithosphere. 
A three-dimensional representation of the Vp model (Fig. 7b) shows that the upper portion of the Ionian slab where $\mathrm{Vp}>$ $8.15 \mathrm{~km} \mathrm{~s}^{-1}$ has the shape of an asymmetric hourglass with its narrowed width at a depth of 100-130 km (yellow dashed lines in Fig. 7b). Furthermore, it is possible to see that the hypocenters of the earthquakes used to obtain the velocity model are located, with similar geometrical features, within the dipping high Vp slab. This characteristic shape suggests the coexistence of vertical and lateral tears of the Ionian slab, and leads us to infer that it is laterally blocked because it is still anchored to the African continental lithosphere (in the western part, beneath the Sicily) and to the Adriatic one (in the eastern part, beneath the Apennines). The presence of the vertical tears is shown in the horizontal section of the Vp model at a depth of $80 \mathrm{~km}$ (Fig. 4, black dashed lines) and agrees with the results discussed by Rosenbaum et al. (2008). However our Vp and Vs models suggest also the presence of horizontal tears (yellow dashed line in Fig. 7b) that are also shown by the sequence of the $\mathrm{Vp}$ horizontal sections (Fig. 5). Although this blockage laterally limits the subduction of the Ionian slab, the roll-back is still active in its central part (as evidenced by the seismicity), down-sucking the slab and consequently tearing it laterally at the borders. Several Authors have suggested the existence of lateral tears in the Ionian slab (Wortel \& Spakman 2000; Spakman \& Wortel 2004; Rosenbaum et al. 2008). The velocity models presented here allow a more detailed description of such tears showing also some strong differences between the eastern tear and the western one (Figs 5, 6 and 7). The eastern lateral tear is observed at a depth of 100-130 km, it is more developed than the western one and, if we consider as the border of the subducting lithosphere the vertical tear displayed in Fig. 5, penetrates into the Ionian slab for about $100 \mathrm{~km}$.

The western lateral tear is less developed (it affects the slab only for few dozen of $\mathrm{km}$ ) and affects the Ionian lithosphere at a depth ranging between 100 and $180 \mathrm{~km}$.

Interesting is also to observe the different pattern of the $\mathrm{Vp} / \mathrm{Vs}$ model in the sections crossing the tears (Appendix B). Section R-R', passing near to the Etna volcano, exhibits high values of the $\mathrm{Vp} / \mathrm{Vs}$ ratio at a depth of $100 \mathrm{~km}$, while the section $\mathrm{H}-\mathrm{H}$ ' show very weak variations of $\mathrm{Vp} / \mathrm{Vs}$ at that depth.

The 3-D sketch of the geodynamic context of the southern Tyrrhenian region (Fig. 7c) is derived from the interpretation of the $\mathrm{Vp}$ and Vs anomalies in Fig. 6 (R-R', S-S', H-H') with the assumption that the average thickness of the Ionian lithosphere is about $125 \mathrm{~km}$ (black dashed lines in Fig. 6, Gvirtzman \& Nur 2001; Pontevivo \& Panza 2006)

We recall that the low velocity volumes recovered in our model are interpreted as partially hydrated (serpentinized) harzburgite. Indeed other tomographic studies have also detected low velocity regions but they are mainly located below the Ionian lithosphere (Piromallo \& Morelli 2003; Spakman \& Wortel 2004; Montuori et al. 2007). Furthermore, their size and amplitude cannot be related to our velocity models and they have been interpreted as lateral mantle flows (Faccenna et al. 2005), and thus considered outside of the Ionian lithosphere.

The model of the Ionian slab with vertical and lateral tears is also supported by secondary constraints coming from the geochemistry of recent magmatism of southern Italy. It is commonly accepted that the 'African' mantle has an isotopic signature enriched in radiogenic lead (HIMU $=$ high- $\mu$, where $\mu$ is the ${ }^{238} \mathrm{U} /{ }^{204} \mathrm{~Pb}$ ratio) with ${ }^{206} \mathrm{~Pb} /{ }^{204} \mathrm{~Pb} \geq 19.4$. The HIMU isotopic signature is present in the recent mafic magmatism around Sicily (Ustica, Hyblean plateau, Etna, Pantelleria, Sicily Channel, Figs 1 and 8, Rotolo et al. 2006 and references therein), but disappears in the Alicudi-Vesuvio tran- sect, to reappear at Mt. Vulture (Fig. 8, De Astis et al. 2006). We suggest that the lack of the HIMU isotopic signature in the Aeolian magmatism (with the exception of Alicudi, Peccerillo et al. 2004) is due to the shield action of the Ionian slab insulating the mantle source of the Aeolian magmatism from the 'African' mantle (Fig. 8). Other authors interpreted this feature as a result of a slab window (Gasperini et al. 2002). However the splitting analysis of the SKS phases splitting (Baccheschi et al. 2007, 2008) suggests a lateral flow of the African mantle around the slab. Doglioni et al. (1999, 2007) suggest that the Tyrrhenian mantle circulation plays a fundamental role on the subduction process and, consequently, on the fore-arc African mantle. They suggest that ENE-WSW Tyrrhenian mantle flows push both the slab and the African mantle eastward facilitating the moving back of the slab. Our results are consistent with the suggestion made by other authors (Faccenna et al. 2005; Rosenbaum et al. 2008 and reference therein) whereby a shielding Ionian slab can explain most of the geochemical features on the magmatism in the study region. Our results support a model of mantle circulation where the African and Tyrrhenian flows both play a fundamental role in the geodynamics of southern Italy.

Besides the influence on the magmatism of southern Italy, the Ionian slab plays an important role in recent lithospheric deformation of eastern Sicily. It is worth noting that the most salient topographical and shallow geological features of the study region, namely the Malta escarpment (topographic expression of the passive margin between the continental portion of the African Plate and the Ionian oceanic crust), the Etna volcano, the strike slip system TindariLetojanni (see Fig. 1) and the Aeolian volcanoes (Vulcano, Lipari and Salina), are aligned approximately in S-N direction (Fig. 8). Here we observe that the western boundary of the reconstructed Ionian slab at a depth of $80 \mathrm{~km}$ (corresponding approximately to the top of the slab) coincides with this alignment. Pondrelli et al. (2004) suggested the presence of this spatial 'coincidence' throughout GPS and seismicity analyses. Here this feature is clearly imaged by the Vp model providing a new constrain for this structural pattern. Furthermore this observation demonstrates the importance of studying the relationships between deep and shallow structures for better understanding some mechanisms of great active structures that involve the terrestrial crust.

\section{CONCLUSIONS}

The detailed reconstruction of $\mathrm{Vp}$ and Vs models allows us to infer new hypotheses on the structure of the Ionian slab and of the surrounding mantle. The vertical sections show high $\mathrm{Vp}$ and $\mathrm{Vs}$ bodies $\left(8.2<\mathrm{Vp}<8.8 \mathrm{~km} \mathrm{~s}^{-1}\right.$ and $\left.4.75<\mathrm{Vs}<5 \mathrm{~km} \mathrm{~s}^{-1}\right)$ $50-60 \mathrm{~km}$ thick and dipping $69^{\circ}-72^{\circ} \mathrm{NW}$ in its steepest part. We assign these velocity distributions to the upper portion of the subducting Ionian slab, which is most likely composed of eclogite and harzburgite having similar seismic properties at that depth (Hacker et al. 2003). Just below, corresponding to the inner portions of the slab, discontinuous low velocity bodies $(7.0<\mathrm{Vp}<7.7 \mathrm{~km}$ $\mathrm{s}^{-1}$ and $3.8<\mathrm{Vs}<4.2 \mathrm{~km} \mathrm{~s}^{-1}$ ), a few dozens of $\mathrm{km}$ wide have been interpreted as partially hydrated (serpentinized) harzburgite. The presence of fluids in this portion of the subducted lithosphere is ascribed to the pervasive presence of fault bends that affect the whole oceanic crust and the upper lithospheric mantle during the bending and subsequent stretching of the steep slab. During the subduction, slab-released fluids are delivered into the overlying mantle wedge, triggering the magmatism in the volcanic arc, whereas additional fluid aliquots find pathways within the slab itself 


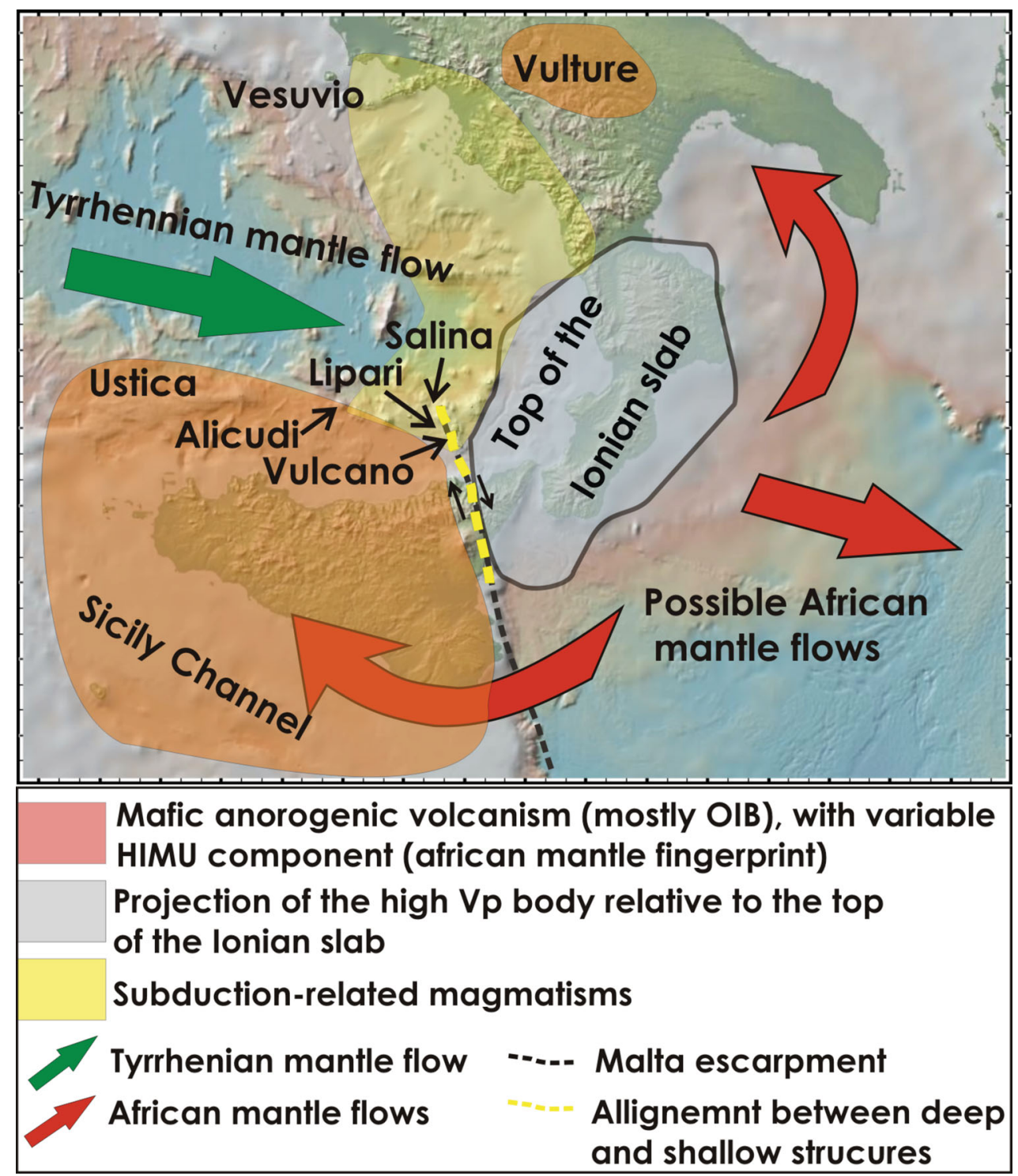

Figure 8. Sketch showing the influence of the Ionian slab on the mantle circulation of the region. The reconstructed shape of the subducting lithosphere allows relating, beside the mantle circulation, the shallow active structures of the Sicilian crust.

affecting the inner ultramafic portion of the subducted lithosphere. This low-velocity region is aseismic, in agreement with the ductile rheology of serpentine-bearing rocks (Peacock \& Hyndmann 1999), and disappears at depths of approximately $230-250 \mathrm{~km}$, which is the experimentally determined upper pressure bound required for the stability of antigorite-chlorite assemblages in hydrous peridotites.

The 3-D reconstruction of the high $\mathrm{Vp}$ body $(\mathrm{Vp}>8.15 \mathrm{~km}$ $\mathrm{s}^{-1}$ ) shows that the upper part of the Ionian slab has a shape of an asymmetric hourglass with its narrowed width at a depth of $100-130 \mathrm{~km}$. This geometry of the Ionian slab suggests both an arcuate shape and the presence of vertical and lateral tears of the subducting lithosphere. These features affect the geochemistry of recent magmatism of southern Italy because the Ionian slab, playing the role of a shield, does not allow the African mantle to be involved in the backarc volcanism (namely the Alicudi-Vesuvio transect) as has been observed during the tracing of the HIMU isotopic signature of the Italian magmatism (De Astis et al. 2006; Rotolo et al. 2006).

\section{ACKNOWLEDGMENTS}

The Study was supported by University of Palermo, INGV, and EOST - University of Strasbourg. We thank very sincerely the Editor and the anonymous reviewers who helped in improving the quality of the manuscript.

\section{REFERENCES}

Abers, G.A., 2005. Seismic low-velocity layer at the top of subducting slabs: observations, predictions, and systematics, Phys. Earth planet. Inter., 149, $7-29$.

Anzidei, M. et al., 1999. First GPS measurements across the Central-Western Mediterranean area, Ann. Geophys., 42(1), 115-120.

Argnani, A., 2000. The southern Tyrrhenian subduction system: recent evolution and neotectonic implications, Ann. Geophys., 43, 585607.

Baccheschi, P., Margheriti, L. \& Steckler, M.S., 2007. Seismic anisotropy reveals focused mantle flow around the Calabrian slab (Southern Italy), Geophys. Res. Lett., 34, doi:10.1029/2006GL028899. 
Baccheschi, P., Margheriti, L. \& Steckle, M.S., 2008. SKS splitting in Southern Italy: anisotropy variations in a fragmented subduction zone, Tectonophysics, 462, 49-67.

Blatt, G. \& Tracy, R.J., 1996. Petrology: Igneous, Sedimentary and Metamorphic, 2nd edn, W. H. Freeman \& Co., New York, NY.

Bruno, G., Guerra, I., Moretti, A. \& Neri, G., 1999. Space variations of stress along the Tyrrhenian Wadati-Benioff zone, Pure appl. Geophys., 156, 667-688.

Caielli, G., Capizzi, P., Corsi, A., De Franco, R., Luzio, D., De Luca, L. \& Vitale, M., 2003. Wide-angle Sea-Land connections as an integration of the CROP MARE II project, Mem. Descr. Carta Geol. d'It., LXII, 55-74.

Calò, M., 2009. Tomography of subduction zones using regional earthquakes: methodological developments and application to the Ionian slab, PhD thesis, EOST, University of. Strasbourg, pp. 1-134. Available at: http://tel.archives-ouvertes.fr/tel-00438598/en/ (last accessed 2009).

Calò, M., Dorbath, C., Cornet, F. \& Cuenot, N., 2011. Large-scale aseismic motion identified through 4-D $P$-wave tomography, Geophys. J. Int., doi:10.1111/j.1365-246X.2011.05108.x.

Calò, M., Dorbath, C., Luzio, D., Rotolo, S.G. \& D’Anna, G., 2008. WAM tomography in the southern Tyrrhenian region. Petrological inferences and hypotheses on the fluid circulation in the subducting Ionian slab and adjoining mantle domain, Bull. Geoph. Theor. Appl., 49(2), 136-141.

Calò, M., Dorbath, C., Luzio, D., Rotolo, S.G. \& D’Anna, G., 2009. Local earthquakes tomography in the southern Tyrrhenian region: geophysical and petrological inferences on subducting lithosphere, in Subduction Zone Geodynamics, Frontiers in Earth Sciences, eds Lallemand, S. \& Funiciello, F., Springer-Verlag, Berlin, doi:10.1007/978-3-540-87974-9.

Carminati, E. \& Doglioni, C., 2004. Mediterranean tectonics, in Encyclopedia of Geology, pp. 135-146, Elsevier, New York, NY, doi:10.1016/B012-369396-9/00135-0.

Catalano, R., Doglioni, C. \& Merlini, S., 2001. On the Mesozoic Ionian Basin, Geophys. J. Int., 144, 49-64.

Chiarabba, C., De Gori, P. \& Speranza, F., 2008. The southern Tyrrhenian subduction zone: deep geometry, magmatism and Plio- Pleistocene evolution, Earth planet. Sci. Lett., 268, 408-423, doi:10.1016/2008.01.036.

Chiarabba, C., Jovane, L. \& DiStefano, R., 2005. A new view of Italian seismicity using 20 years of instrumental recordings, Tectonophysics, 395(3-4), 251-268, doi:10.1016/j.tecto.2004.09.013.

Chironi, C., De Luca, L., Guerra, I., Luzio, D., Moretti, A., Vitale, M., SEALAND Group, 2000. Crustal structures of the Southern Tyrrhenian Sea and the Sicily Channel on the basis of the M25, M26, M28, M39 WARR profiles, Boll. Soc. Geol. It., 119, 189-203.

Christensen, N.I., 2004. Serpentinites, peridotites and seismology, Int. Geol. Rev., 46, 795-816.

Connolly, J.A.D. \& Kerrick, D.M., 2002. Metamorphic controls on seismic velocity of subducted oceanic crust at 100-250 km depth, Earth planet. Sci. Lett., 204, 61-74.

Davies, J.H. \& Stevenson, D.J., 1992. Physical model of source region of subduction zone volcanics, J. geophys. Res., 97, 2037-2070.

De Astis, G., Kempton, D., Peccerillo, A. \& Wu, T.W., 2006. Trace element and isotopic variations from Mt. Vulture to Campanian volcanoes: constraints for slab detachment and mantle inflow beneath Southern Italy, Contrib. Mineral. Petrol., 151, 331-351, doi:10.1007/s00410-0060062-y.

Dobson, D.P., Meredith, G. \& Boon, S.A., 2002. Simulation of subduction zone seismicity by dehydration of serpentine, Science, 298, 1407-1408.

Doglioni, C., Carminati, E., Cuffaro, M. \& Scrocca, D., 2007. Subduction kinematics and dynamic constraints, Earth-Sci. Rev., 83,125-175.

Doglioni, C., Gueguen, E., Harabaglia, P. \& Mongelli, F., 1999. On the origin of W-directed subduction zones and applications to the western Mediterranean, Geol. Soc. London Spec. Publ., 156, 541-561, doi:10.1144/GSL.SP.1999.156.01.24.

Dorbath, C., Gerbault, M., Carlier, G. \& Guiraud, M., 2008. Double seismic zone of the Nazca plate in northern Chile: high-resolution velocity structure, petrological implications, and thermomechanical modeling, Geochem. Geophys. Geosyst., 9(Q07006), doi:10.1029/2008GC002020.

Eberhart-Phillips, D. \& Reyners, M., 1997. Continental subduction and three-dimensional crustal structure: the northern South Island, New Zealand, J. geophys. Res., 102, 11 843-11 861.

Evans, J.R., Eberhart-Phillips, D. \& Thurber, C.H., 1994. User's manual for SIMULPS12 for imaging Vp and Vp/Vs: a derivative of the "thurber" tomographic inversion SIMUL3 for local earthquakes and explosions. USGS Open File Rep., 94-431.

Faccenna, C., Civetta, F., D’Antonio, M., Funiciello, F., Margheriti, L. \& Piromallo, C., 2005. Constraints on mantle circulation around the deforming Calabrian slab, Geophys. Res. Lett., 32, doi:10.1029/2004GL021874.

Finetti, I.R., 2005. The Calabrian arc and subducting Ionian slab from new CROP seismic data, Crop Project: Deep Seismic Exploration of the Central Mediterranean and Italy, pp. 393-412, Elsevier, New York, NY.

Fumagalli, P. \& Poli, S., 2005. Experimentally determined phase relations in hydrous peridotites to $6.5 \mathrm{GPa}$ and their consequences on the dynamics of subduction zones, J. Petrol., 46, 555-578.

Gasperini, D., Blichert-Toft, J., Bosch, D., Del Moro, A., Macera, P. \& Albaréde, F., 2002. Upwelling of deep mantle material through a plate window: evidence from the geochemistry of Italian basaltic volcanic, $J$. geophys. Res., 107(B12), 2367, doi:10.1029/2001JB000418.

Giunta, G. et al., 2004. The Palermo (Sicily) seismic cluster of September 2002 in the seismotectonic framework of the Tyrrhenian Sea-Sicily border area, Ann. Geophys., 47(6), 1755-1770.

Goes, S., Giardini, D., Jenny, S., Hollenstein, C., Kahle, H.G. \& Geiger, A., 2004. A recent tectonic reorganization in the south-central Mediterranean, Earth planet. Sci. Lett., 226, 335-345, doi:10.1016/j.eps1.2004.07.038.

Gvirtzman, Z. \& Nur, A., 2001. Residual topography, lithospheric structure and sunken slab in the central Mediterranean, Earth planet. Sci. Lett., 187, 117-130.

Hacker, B.R., Abers, G.A. \& Peacock, S.M., 2003. Subduction factory 1) Theoretical mineralogy, densities, seismic wave speeds, and $\mathrm{H}_{2} \mathrm{O}$ contents, J. geophys. Res., 108(B1), 2029, doi:03311-10.129/2001JB001127.

Hollenstein, Ch., Kahle, H.-G., Geiger, A., Jenny, S., Goes, S. \& Giardini, D., 2003. New GPS constraints on the Africa-Eurasia plate boundary zone in Southern Italy, Geophys. Res. Lett., 30(18), 1935, doi:10.1029/2003GL017554.

Jung, H. \& Karato, S.-I., 2001. Water-induced fabric transitions in olivine, Science, 293, 1460-1463.

Kastens, K. et al., 1988. ODP Leg 107 in the Tyrrhenian sea: insights into passive margin and back-arc basin evolution, Bull. geol. Soc. Am., 100, $1140-1156$

Kerrick, D., 2002. Serpentinite seduction, Science, 298, 1344-1345, doi:10.1126/science.298.5597.134

Koulakov, I., Kaban, M.K., Tesauro, M. \& Cloetingh, S., 2009. P- and $S$ velocity anomalies in the upper mantle beneath Europe from tomographic inversion of ISC data, Geophys. J. Int., 179, 345-366, doi:10.1111/j.1365246X.2009.04279.x.

Malinverno, A. \& Ryan, W.B.F., 1986. Extension on the Tyrrhenian Sea and shortening in the Apennines as result of arc migration driven by sinking of the lithosphere, Tectonics, 5, 227-245.

Montuori, C., Cimini, G.B. \& Favali, P., 2007. Teleseismic tomography of the southern Tyrrhenian subduction zone: new results from seafloor and land recordings, J. geophys. Res., 112, 3311, doi:10.129/2005 JB004114.

Neri, G., Orecchio, B., Totaro, C., Falcone, G. \& Presti, D., 2009. Subduction beneath Southern Italy close the ending: results from seismic tomography, Seism. Res. Lett., 80, 63-70.

Panza, G.F. \& Suhadolc, P., 1990. Properties of the lithosphere in collisional belts in the Mediterranean - a review, Tectonophysics, 182, 39 46.

Peacock, S.M., 2001. Are the lower planes of double seismic zones caused by serpentine dehydration in subducting oceanic mantle, Geology, 29, 299-302.

Peacock, S.M. \& Hyndmann, R.D., 1999. Hydrous minerals in the mantle wedge and the maximum depth of subduction thrust earthquakes, Geophys. Res. Lett., 26, 2517-2520.

Peccerillo, A., Dallai, L., Frezzotti, M.L. \& Kempton, P.D., 2004 $\mathrm{Sr}-\mathrm{Nd}-\mathrm{Pb}-\mathrm{O}$ isotopic evidence for decreasing crustal contamination with ongoing magma evolution at Alicudi volcano (Aeolian arc, Italy): 
implications for style of magma-crust interaction and for mantle source compositions, Lithos, 78, 217-233, doi:10.1016/j.lithos.2004.04.040.

Pepe, F., Sulli, A., Bertotti, G. \& Cella, F., 2008. Crustal architecture and Miocene to recent evolution of the W Calabria continental margin (Southern Tyrrhenian Sea), Ext. abs. Miscellanea-INGV, 3, 98-99.

Piromallo, C. \& Morelli, A., 2003. P wave tomography of the mantle under the Alpine-Mediterranean area, J. geophys. Res., 108(B2), 2065, doi:10.1029/2002JB001757.

Poli, S. \& Schmidt, M.W., 1995. H2O transport and release in subduction zones: experimental constraints on basaltic and andesitic systems, J. geophys. Res., 100, 22299-22314.

Pondrelli, S., Piromallo, C. \& Serpelloni, E., 2004. Convergence vs. retreat in Southern Tyrrhenian Sea: insights from kinematics, Geophys. Res. Lett., 31, L06611, doi:10.1029/2003GL019223.

Pontevivo, A. \& Panza, G.F., 2006. The Lithosphere-Astenosphere system in the Calabrian arc, Pure appl. Geophys., 163, 1617-1659.

Ranero, C.R., Phipps Morgan, J., McIntosh, K. \& Reichert, C., 2003. Bending-related faulting and mantle serpentinization at the Middle America trench, Nature, 425, 367-373.

Rosenbaum, G., Gasparon, M., Lucente, F., Peccerillo, A. \& Miller, M.S., 2008. Kinematics of slab tear faults during subduction segmentation and implications for Italian magmatism, Tectonics, 27, TC2008, doi:10.1029/2007TC002143.

Rosenbaum, G. \& Lister, G.S., 2004. Formation of arcuate orogenic belts in the western Mediterranean region, in Orogenic Curvature: Integrating Paleomagnetic and Structural Analyses, Geol. Soc. Am. Spec. Paper Vol. 383, pp. 41-56, eds Sussman, A.J. \& Weil, A.B., Geological Society of America, Boulder, CO.

Rotolo, S.G., Castorina, F., Cellura, D. \& Pompilio, M., 2006. Petrology and geochemistry of submarine volcanism in the Sicily Channel Rift, J. Geol., 114, 355-365.

Rupke, L.H., Morgan, J.P., Hort, M. \& Connolly, J.A.D., 2004. Serpentine and the subduction zone water cycle, Earth planet. Sci. Lett., 223, $17-34$.

Sartori, R., 2003. The Tyrrhenian back-arc basin and subduction of the Ionian lithosphere, Episodes, 26, 217-221.
Schmidt, M.W. \& Poli, S., 1998. Experimentally based water budgets for dehydrating slabs and consequences for arc magma generation, Earth planet. Sci. Lett., 163, 361-379.

Shelly, D.R., Beroza, G.C., Zhang, H., Thurber, C.H. \& Ide, S., 2006. High resolution subduction zone seismicity and velocity structure beneath Ibaraki Prefecture, Japan, J. geophys. Res., 111, B06311, doi:10.1029/2005JB004081.

Spakman, W. \& Wortel, R., 2004. A tomographic view on western Mediterranean Geodynamics, The Transmed Atlas: The Mediterranean Region from Crust to Mantle, pp. 31-52, Springer-Verlag, Heidelberg.

Thurber, C.H., 1993. Local earthquake tomography: velocity and Vp/Vs theory, in Seismic Tomography: Theory and Practice, pp. 563-580, eds Iyer, H.M. \& Hirahara, K., CRC Press, Boca Raton, FL.

Tommasini, S., Heumann, A., Avanzinelli, R. \& Francalanci, L. 2007. The fate of high-angle dipping slabs in the subduction factory: an integrated trace element and radiogenic isotope $(\mathrm{U}, \mathrm{Th}, \mathrm{Sr}, \mathrm{Nd}, \mathrm{Pb})$ study of Stromboli Volcano, Aeolian Arc, Italy, J. Petrol., 48, 2407-2430.

Toomey, D.R. \& Foulger, G.R., 1989. Tomography inversion of local earthquake data from the Hengill: Grensdalur central volcano complex, Iceland, J. geophys. Res., 94(B12), 17 497-17 510.

Waldhauser, F. \& Ellsworth, W.L., 2000. A double-difference earthquake location algorithm: method and application to the northern Hayward Fault, California, Bull. seism. Soc. Am., 93, 1353-1368.

Wortel, R. \& Spakman, W., 2000. Subduction and slab detachment in the Mediterranean-Carpathian region, Science, 290, 1910, doi:10.1126/science.290.5498.1910.

Zhang, H. \& Thurber, C.H., 2003. Double-difference tomography: the method and its application to the Hayward fault, California, Bull. seism. Soc. Am., 93, 1175-1189.

Zhang, H., Thurber, C.H., Shelly, D., Ide, S., Beroza, G.C. \& Hasegawa, A., 2004. High-resolution subducting-slab structure beneath northern Honshu, Japan, revealed by double-difference tomography, Geology, 32, 361-364, doi:10.1130/G20261.2.

Zhao, D., Hasegawa, A. \& Horiuchi, S., 1992. Tomographic imaging of P and $\mathrm{S}$ wave velocity structure beneath northeastern Japan, J. geophys. Res., 97, 19909-19928. 

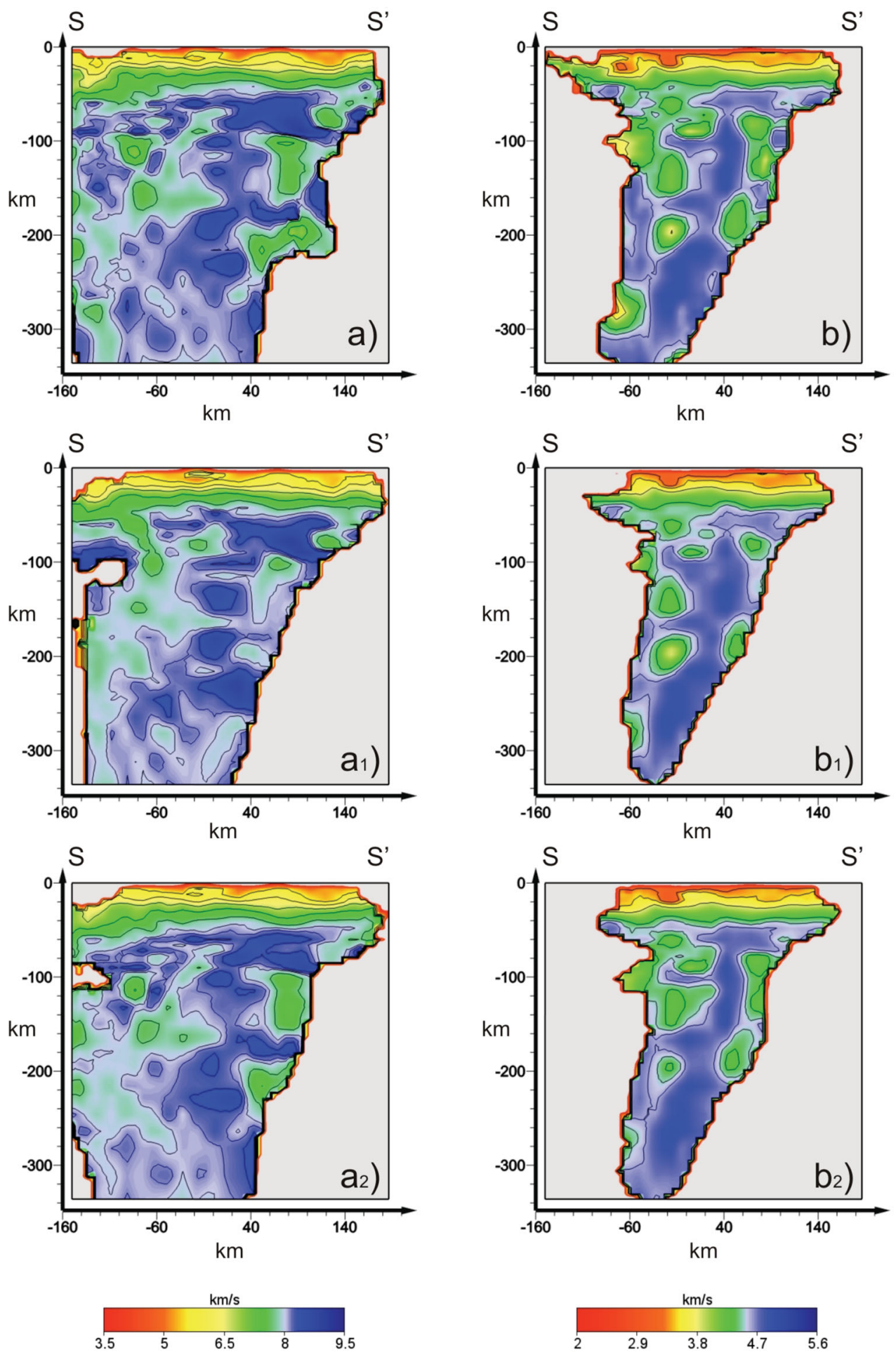

Figure A1. Panels (a) and (b) display the S-S' sections of the Vp and Vs models calculated using the whole data set. Panels $\left(a_{1}\right)$ and $\left(b_{1}\right)$ show the results of the inversions obtained selecting the odd numbers of event list and panels $\left(\mathrm{a}_{2}\right)$ and $\left(\mathrm{b}_{2}\right)$ the even ones. The well-resolved area of the inversions performed with the two independent events is smaller because we adopted the same DWS threshold (DWS $=100$ ) that we used to obtain the model with the complete data set. 
APPENDIX B
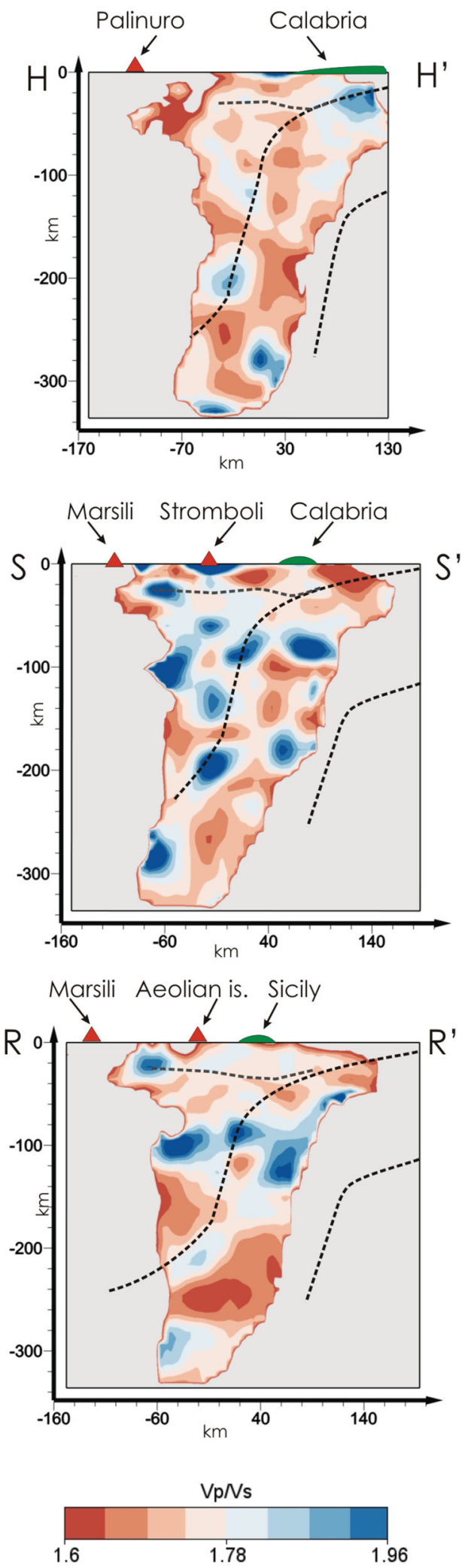

Figure B1. Vertical sections of the Vp/Vs model computed by dividing the Vp and Vs WAMs. The well-resolved area is enclosed by DWS values of the Vs model. The threshold used is DWSs $=200$. 